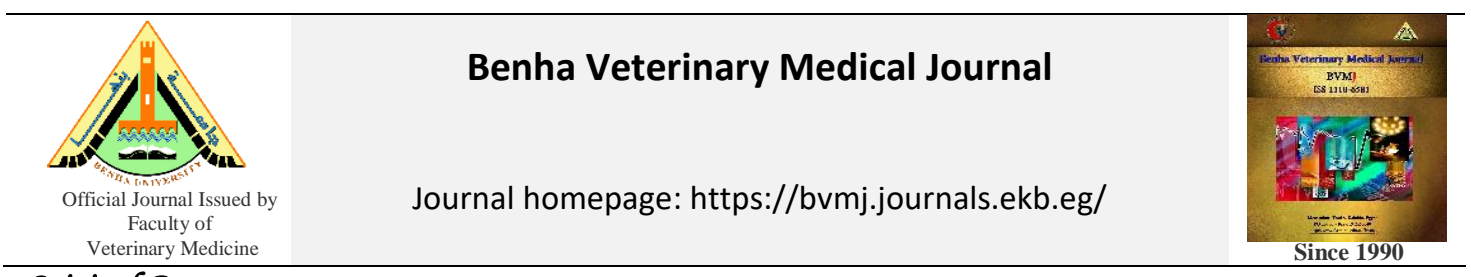

Original Paper

\title{
Prevalence of some chemical hazards in some meat products
}

\author{
Wafaa Hazaa ${ }^{1}$, Fahim Shaltout ${ }^{1}$, Mohamed El-Shater ${ }^{2}$ \\ ${ }^{1}$ Department of Food Hygiene, Faculty of Veterinary Medicine, Benha University, Egypt \\ ${ }^{2}$ Department of Food Hygiene, Animal Health Research Institute, Dokki, Giza, Egypt
}

\section{ARTICLE INFO}

\begin{tabular}{l}
\hline Keywords \\
Chemical hazards \\
Cadmium \\
Lead \\
Meat products \\
Nitrite \\
\hline Received 04/08/2019 \\
Accepted 05/10/2019 \\
Availa6le On-Line \\
12/05/2020
\end{tabular}

\begin{abstract}
In an attempt to determine the prevalence of some chemical hazards in various meat product by measuring the residual levels of lead $(\mathrm{Pb})$, cadmium $(\mathrm{Cd})$ and nitrite in such product, a total number of 60 random samples (15 of each) of minced meat, beef burger, sausages and luncheon were haphazardly gathered from a varied supermarkets and retailers in Benha City at Kalubia governorate, Egypt to be chemically analyzed by means of spectrophotometer. From the achieved results, the mean values of residual levels of $\mathrm{Pb}$ in the inspected samples of minced meat, beef burger, sausages and luncheon were $0.06 \pm 0.01,0.11 \pm 0.01,0.16 \pm$ 0.01 and $0.23 \pm 0.01 \mathrm{mg} / \mathrm{kg}$, respectively, while those of $\mathrm{Cd}$ were $0.03 \pm 0.01,0.07 \pm 0.01$, $0.12 \pm 0.01$, and $0.15 \pm 0.01 \mathrm{mg} / \mathrm{kg}$, and finally those of nitrite were not detected, $39.81 \pm$ $2.24,27.59 \pm 1.65$ and $62.07 \pm 2.51(\mathrm{ppm})$, respectively. The obtained findings were complied with the acceptable limits of heavy metals residues and residual nitrite level recommended by Egyptian Standards.
\end{abstract}

\section{INTRODUCTION}

Meat products play an important role in filling the gap of protein deficiency and they can be considered the best choice in solving human nutritional problems (IbrahimEman, 2008), but it may harbor a hazards to human health through long chain of preparation, handling of raw meat, equipment, processing, distribution storage and retailing (Maricica et al., 2014).

Hazards are agents that cause illness or injury to the human within absence of its control and are classified into three types: biological, chemical and physical hazards. Whereas, the biological hazards can cause widespread illness outbreaks, chemical hazards may also cause food-borne diseases (USDA, 1997) beside to, long term health problems for the consumers of food products (Islam and Hoque , 2013). Chemical hazards are most often associated with raw materials, ingredients and personnel practices that include heavy metals, pesticides, veterinary medicines, cleaning compounds, allergens and some food additives (NZFSA, 2012).

Heavy metal pollutants can contaminate meat product in the course of processing through raw material, spices, packaging materials and packaging method and it considered as a great concern risk for food safety and human health because of their toxic nature at comparatively minute concentrations and their ability to accumulate within the body organs (Santhi et al., 2008). Also, they considered as a potential carcinogen besides causing a number of disorders in cardiovascular, nervous and skeletal systems (Zhuang et al., 2010).
Lead is metabolic poison and neurotoxin that binds to essential enzymes and several other cellular components and inactivates them (Cunningham and Saigo, 1997).

Cadmium is classified as a probable human carcinogen also chronic exposure to cadmium is associated with a wide range of diseases including heart diseases, anemia, skeletal weakness, depressed immune system response as well as kidney and liver disorders (Codex Alimentarius, 2001).

Some food additives as nitrite may also be hazardous if present above permissible limit (NZFSA, 2012). Nitrite have been conventionally utilized as curing agents in the production of some meat products for improvement of the quality as well as the microbiological safety because it features a role in the development of the distinct flavor, the steadiness of the red color and shield against lipid oxidation. Moreover, it shows significant bacteriostatic and/or bactericidal activity against several spoilage microorganisms and it hinder the growth and toxin production by Clostridium botulinum (Govari and Pexara, 2015). Meanwhile, using of nitrite in food has been clouded by doubts in which it could react with amines in the gastric acid and form carcinogenic nitrosamines, leading to various cancers production (Archer, 2002).

Therefore, the aim of this study was to estimate the level of lead cadmium and nitrite content in some meat products to evaluate the acceptability of such products according to the specification stipulated by Egyptian Standards.

\section{MATERIAL AND METHODS}

2.1. Collection of samples:

A total 60 random samples of meat products represented by 15 samples (about350 gm) of each of minced meat,

\footnotetext{
* Corresponding author Prof Fahim Shaltout. Department of Food Hygiene, Faculty of Veterinary Medicine, Benha University, Egypt
} 
beef burger, sausage and luncheon that were collected from different supermarkets and shops in Benha City, Kalubia governorate, Egypt.

These samples were obtained in their intact original package and preserved in an ice box then transferred to the laboratory without undue delay and examined as rapidly as possible.

\subsection{Determination of heavy metals:}

The collected samples were examined for determination of their lead and cadmium levels on the basis of wet weight $(\mathrm{mg} / \mathrm{Kg})$.

- Washing procedures according to (AOAC, 2006).

- Digestion technique according to (Tsoumboris and Papodoulou, 1994).

- Preparation of blank and standard solutions according to (Shibamoto and Bjeldanes, 2000).

- Analysis using Flame Atomic Absorption Spectrophotometer (VARIAN, model AA240 FS, Australia).

- Quantitative determination of heavy metals: Absorbency of lead and cadmium was directly recorded from the digital scale and their concentrations were calculated according to the following equation: $\mathrm{C}=\mathrm{R} \mathrm{x}$ (D/W) Where, $\mathrm{C}=$ Concentration of the element (wet weight). $\mathrm{R}=$ Reading of digital scale of $\mathrm{AAS}, \mathrm{D}=$ Dilution of the prepared sample and $\mathrm{W}=$ Weight of the sample.

\subsection{Determination of residual nitrite level:}

Nitrite level was determined spectrophotometrically according to (AOAC, 2016).

\section{RESULTS}

The achieved findings in table (1) clarified that the lead levels $(\mathrm{mg} / \mathrm{kg})$ in the tested samples of meat product were ranged from 0.01 to 0.09 at a mean value of $0.06 \pm 0.01$ for minced meat, 0.02 to 0.17 at a mean value $0.11 \pm 0.01$ for beef burger, 0.02 to 0.25 at a mean value $0.16 \pm 0.01$ for sausage and 0.07 to 0.38 at a mean value $0.23 \pm 0.01$ for luncheon .Also, there were a highly significant differences $(\mathrm{p}<0.01)$ between the examined samples, as appeared in table (1). Furthermore, the detectable samples above the acceptable limit stipulated by (ES. 2010) were 5 samples $(8.3 \%)$ from all of the studied samples as declared in table (2).

Table 1 Lead levels $(\mathrm{mg} / \mathrm{Kg})$ in the examined samples of meat products $(\mathrm{n}=15)$

\begin{tabular}{lccc}
$(\mathrm{n}=15)$. & Min & Max & Mean \pm S.E \\
\hline Meat products & 0.01 & 0.09 & $0.06 \pm 0.01^{++}$ \\
\hline Minced meat & 0.02 & 0.17 & $0.11 \pm 0.01^{++}$ \\
Beef burger & 0.02 & 0.25 & $0.16 \pm 0.01^{++}$ \\
Sausage & 0.07 & 0.38 & $0.23 \pm 0.01^{++}$ \\
Luncheon & &
\end{tabular}

Table 2 Acceptability of the examined samples of meat products based on their contamination levels of lead $(\mathrm{n}=15)$.

\begin{tabular}{lccccc}
\hline Meat products & Lead (PL)* & \multicolumn{2}{c}{ Accepted } & \multicolumn{2}{c}{ Unaccepted } \\
\cline { 3 - 6 } & & No & $\%$ & No & $\%$ \\
\hline Minced meat & $<0.1$ & 15 & 100 & 0 & 0 \\
Beef burger & $<0.1$ & 14 & 93.3 & 1 & 6.7
\end{tabular}

\begin{tabular}{lccccc} 
Sausage & $<0.1$ & 13 & 86.7 & 2 & 13.3 \\
Luncheon & $<0.1$ & 13 & 86.7 & 2 & 13.3 \\
Total & & 55 & 91.7 & 5 & 8.3 \\
\hline "Egyptian Standards "ES" (2010). & & & &
\end{tabular}

Results obtained in table (3) declared that the Cd levels $(\mathrm{mg} / \mathrm{kg})$ in the studied samples were ranged from 0.01to 0.04 with a mean values of $0.03 \pm 0.01$ for minced meat samples, 0.01 to 0.15 with a mean values of $0.07 \pm 0.01$ for beef burger, 0.01 to 0.19 with a mean values of $0.12 \pm 0.01$ for sausage and 0.02 to 0.27 with a mean values of $0.15 \pm$ 0.01 for luncheon. Also, there were a highly significant differences $(p<0.01)$ in $\mathrm{Cd}$ values between the examined samples. Wherein, $6.7 \%$ of the studied samples were above the permissible limits stipulated by (ES, 2010) for Cd level, as declared in table (4).

Table 3: Cadmium levels $(\mathrm{mg} / \mathrm{Kg})$ in the examined samples of meat products $(\mathrm{n}=15)$.

\begin{tabular}{llll} 
products $(\mathrm{n}=15)$. & & & \\
\hline Meat products & Min & Max & Mean \pm S.E \\
\hline Minced meat & 0.01 & 0.04 & $0.03 \pm 0.01^{++}$ \\
Beef burger & 0.01 & 0.15 & $0.07 \pm 0.01^{++}$ \\
Sausage & 0.01 & 0.19 & $0.12 \pm 0.01^{++}$ \\
Luncheon & 0.02 & 0.27 & $0.15 \pm 0.01^{++}$ \\
\hline
\end{tabular}

${\mathrm{S} . \mathrm{E}^{*}}^{*}$ standard error of mean. ++ = High significant differences $(\mathrm{P}<0.01)$

Table 4: Acceptability of the examined samples of meat products based on levels of cadmium $(\mathrm{n}=15)$

\begin{tabular}{lccccc}
\hline Meat products & $\begin{array}{c}\text { Cadmium } \\
(\mathrm{PL})^{*}\end{array}$ & \multicolumn{2}{c}{ Accepted } & \multicolumn{2}{c}{ Unaccepted } \\
\cline { 3 - 6 } & & No & $\%$ & No & $\%$ \\
\hline Minced meat & $<0.05$ & 15 & 100 & 0 & 0 \\
Beef burger & $<0.05$ & 14 & 93.3 & 1 & 6.7 \\
Sausage & $<0.05$ & 14 & 93.3 & 1 & 6.7 \\
Luncheon & $<0.05$ & 13 & 86.7 & 2 & 13.3 \\
Total & & 56 & 93.3 & 4 & 6.7 \\
\hline
\end{tabular}

*Egyptian Standards "ES" (2010).

It is evident from findings recorded in table (5) that the mean values of nitrite levels (ppm) in the investigated samples of meat product were $62.07 \pm 2.51$ for luncheon samples, $27.59 \pm 1.65$ for sausage samples and $39.81 \pm$ 2.24 for beef burger samples. Meanwhile, nitrite was not detected in all of the examined minced meat samples. Also, the differences between the assessed samples of meat products as a result of types of the products were significantly differences $(p<0.05)$. Depending on the MPL of nitrite levels stipulated by (ES, 2005) all of the tested samples of meat product were accepted except only one luncheon sample (1.7\%) was unaccepted, as declared in table (6).

Table 5: Nitrite contents (ppm) in the examined samples of meat products $(\mathrm{n}=15)$

\begin{tabular}{llll}
\hline Meat products & Min & Max & Mean \pm S.E \\
\hline Minced meat & - & - & - \\
Beef burger & 17.1 & 65.3 & $39.81 \pm 2.24^{+}$ \\
Sausage & 12.8 & 43.5 & $27.59 \pm 1.65^{+}$ \\
Luncheon & 25.6 & 103.2 & $62.07 \pm 2.51^{+}$ \\
\hline
\end{tabular}

${\mathrm{S} . E^{*}}^{*}$ standard error of mean. $++=$ High significant differences $(\mathrm{P}<0.01)$

Table 6: Acceptability of the examined samples of meat products-based nitrite contents $(\mathrm{n}=15)$.

\begin{tabular}{lllll} 
Meat products & $\begin{array}{c}\text { Nitrite } \\
(\mathrm{PL})^{*}\end{array}$ & \multicolumn{2}{c}{ Accepted } & \multicolumn{2}{c}{ Unaccepted } \\
\cline { 3 - 5 } & & No & $\%$ & No
\end{tabular}




\begin{tabular}{lccccc}
\hline Minced meat & $<100$ & 15 & 100 & 0 & 0 \\
Beef burger & $<100$ & 15 & 100 & 0 & 0 \\
Sausage & $<100$ & 15 & 100 & 0 & 0 \\
Luncheon & $<100$ & 14 & 93.3 & 1 & 6.7 \\
Total & & 59 & 98.3 & 1 & 1.7 \\
\hline
\end{tabular}

\section{DISCUSSION}

Generally, chemical hazards in meat products can originate from 1- Unintentionally added chemicals (Agriculture chemicals as pesticides and animal drugs, Plant chemicals as cleaners, sanitizers, oils and lubricants and also Environmental contaminants as heavy metals) 2. Naturallyoccurring chemical: as products of plant, animal, or microbial metabolisms such as aflatoxins, etc. 3.Intentionally added chemicals (preservatives, food additives, processing aids, etc.) (USDA, 1997).

Heavy metals are chemical items, that can't be broken down or diminished in the course of heat treatment and it can promote multiple hazards on human health that may be acute or chronic lethal or sub lethal toxicity (Shaltout $e t$ al, 2015). Meat processing can provide a doable supply of heavy metals contamination in the ultimate products additionally the improvement in the food production and processing technology are increasing the probabilities of food contamination with numerous environmental pollutants, particularly heavy metals( Lukáčová -Anetta et al., 2014). Results achieved in table (1) clarified that the mean values of lead levels $(\mathrm{mg} / \mathrm{kg})$ in the tested meat product samples were $0.06 \pm 0.01,0.11 \pm 0.01,0.16 \pm 0.01$ and $0.23 \pm 0.01$ for minced meat, beef burger sausage and luncheon samples, respectively. Also, there were a highly significant differences $(\mathrm{p}<0.01)$ between the investigated products. This findings were almost identical to that obtained by Zahran- Dalia and Hendy- Bassma (2015) $(0.18 \pm 0.13 \mathrm{ppm})$ for sausage samples but exceeding that obtained Adejumo et al. (2016), who recorded that lead can't be detected in any of the studied samples of meat product and additionally under that obtained by MeslamEbtsam (2018)(0.13 $\pm 0.01 \mathrm{mg} / \mathrm{kg})$ in minced meat. Absorption of ingested lead may constitute a serious risk to public health especially in young children who considered at high risk to lead toxicity, owing to their ability to effectively lead absorption leading to retardation of mental and physical development (Karovicova and Kohajdova, 2005). Meanwhile, lead toxicity in adult ends up in GI tract damage, procreative capability dysfunction, nephropathies, CNS damage, adverse blood effects due to interference to the enzymatic system that synthesize the HEME group (Rubio et al., 2005). In accordance with the accepted permissible limit $(<0.1 \mathrm{ppm})$ specified by (ES, 2010) for lead level in meat product it was expressed that out of the examined 60samples of meat products $8.3 \%$ (5 samples) were considered as unaccepted which including $0 \%$ (0-sample), $6.7 \%$ (1 samples), $13.3 \%$ (2 sample) and
$13.3 \%$ ( 2 samples) for the assessed samples of minced meat, beef burger, sausage and luncheon, respectively as declared in table (2).The excessive lead intake above the permissible limits leads to joints, muscles and nerve disorders other than cardiovascular/skeletal and renal problems (Environmental Working Group, 2010).

Results obtained in table (3) declared that the mean values of $\mathrm{Cd}$ levels $(\mathrm{mg} / \mathrm{kg})$ in the inspected minced meat, beef burger, sausage and luncheon samples were $0.03 \pm 0.01$, $0.07 \pm 0.01,0.12 \pm 0.01$ and $0.15 \pm 0.01$, respectively. Also, there were a highly significant differences $(\mathrm{p}<0.01)$ in $\mathrm{Cd}$ values between the examined products. These findings were nearly similar to those obtained Gabriel Hoha et al. (2014) $(0.16 \pm 0.008 \mathrm{mg} / \mathrm{kg})$ and Zahran- Dalia and Hendy- Bassma (2015) (0.11 \pm 0.8ppm) in luncheon samples. Although, higher findings were detected by Meslam- Ebtsam (2018) $(0.07 \pm 0.01 \mathrm{mg} / \mathrm{kg})$ for minced meat samples. Meanwhile, lower results were achieved by Shahat et al. (2017) who showed that Cadmium wasn't detected in minced meat samples. It is obvious from the obtained findings that recorded in table (4) that $6.7 \%$ of the total examined samples $(4 / 60)$ were unaccepted where the highest incidence of unacceptability of the inspected meat product samples was recorded in luncheon samples $13.3 \%$ (2/15samples), followed by sausage and beef burger samples $6.7 \%$ (1/15 sample for both) this is due to the detected level of cadmium concentration which exceeds the permissible limit predetermined by (ES, 2010) that was $(<0.05 \mathrm{ppm})$. Meanwhile, all of the tested samples of minced meat were considered as accepted as the detected $\mathrm{Cd}$ levels were below the permissible limit. In humans, cadmium are known to develop a range of toxic effects at the side of carcinogenic and non-carcinogenic effects as oral exposure to high levels of cadmium has cause severe stomach irritation, leading to vomiting and diarrhea, whereas exposure to lower levels over time has been found to cause excretory organ damage, bone deformity and simply broken bones (ATSDR, 2008) beside to, many other effects such as neurotoxic, genotoxic, carcinogenic, and teratogenic effects (EFSA, 2009).

From the obtained results of both lead and cadmium level it was obvious that minced meat has a lower level of lead and cadmium this may be attributed to decreased processing steps for minced meat compared to other products at which contamination may occur during processing from the contact with machinery, tools, and installations or after some technological processes (as smoking, drying and salting) (Manea et al., 2017).

Using of nitrite in meat processing as preservatives has an essential role in overriding of meat spoilage as well as in in manufacturing safeand appetizing meat product with wel 1 keeping quality even at surrounding temperature (Skibsted, 2011). Regarding to data obtained in table (5) it is obvious that the nitrite content in the investigated meat products samples (ppm) varied from 25.6 to103.2 with an 
average of $62.07 \pm 2.51$ for luncheon samples, 12.8 to 43.5 with an average of $27.59 \pm 1.65$ for sausage samples, 17.1 to65.3 with an average of $39.81 \pm 2.24$ for beef burger samples. Meanwhile, nitrite was not detected in all of the tested minced meat samples while the highest nitrite level was detected in the examined luncheon samples followed by beef burger samples and the lowest nitrite level was detected in sausage samples. Also, the differences associated with the inspected samples of meat products as a result of types of the products were significantly differences $(p<0.05)$. This results came in agreement with those reported by Ez-Eldain-Afaf and El-Nemr (2016) who reported that the mean value of nitrite in the observed luncheon samples was $(80 \pm 7.3 \mathrm{ppm})$ but disagreed with lower findings attained by El-Zahaby (2013) that was $(17.68 \mathrm{ppm})$ in the tested samples of beef burger and higher results detected by Nayel (2013) who concluded that the mean value of nitrite level in the examined burger samples was $(94.04 \pm 5.20 \mathrm{ppm})$ and Meslam-Ebtsam (2018) that was (24.14ppm) in minced meat samples. The high residual levels of nitrites could be attributed to inappropriate production states and faulty or improper implementation of nitrite standard levels at meat product plant (Rezaei et al., 2013). Nitrites are considered safe once used at accepted level but can perform a hazard when this level exceeded consequently, the increasing levels of nitrite are becoming an important problem for public health (Cemek et al., 2007). The primary toxic impact of nitrite is the creation of methemoglobin by oxidation of hemoglobin, this compound is incapable of transporting oxygen in the blood, leading to a condition referred to as methemoglobinemia (Santamaria, 2006). Also, the longterm toxicity of nitrites is expounded to their potential to form carcinogenic compounds within the food likewise as in the human body (Andree et al., 2010). At which the residual nitrite can be regenerate to the nitro-sating agent which react with secondary amines and form carcinogenic compounds (carcinogenic N-nitrosamines) (Honikel, 2008). Results obtained in table (6) indicating that based on the permissible limit of residual nitrite content specified by Egyptian standards (ES , 2005) $(<100 \mathrm{ppm})$, out of the examined 60 samples of $98.3 \%$ (59 samples ) were considered as acceptable while $1.7 \%$ (one sample) were categorized as unacceptable. The high nitrite level in few of the observed samples may be attributed to elusiveness through inaccuracy of its level during the processing of meat products in relation to prolongation of their shelf-life since, the most important aim of some producers is the economic income regardless to the adverse effect of the used preservatives on the consumers health (Farag and Abd-El- Fatah-Noha, 2011).

\section{CONCULOSIONS}

The achieved results demonstrated a highly significant differences existed in the concentrations of lead and cadmium metals across the inspected meat product samples. Moreover, the concentrations of nitrite residues in the examined products were differed significantly. All samples except minced meat have some of unaccepted levels of lead, cadmium and nitrite. Therefore, it is recommended that a periodic monitoring of these products is important with respect to such chemical hazards that affecting human health.

\section{REFERENCES}

1. Adejumo, O. E., Pius, S. F., Odion, J. E., Silva, B. O. and Fajemirokum, T.O. 2016. High Cadmium Levels in Cured Meat Products Marketed in Nigeria-Implications for Public Health. Asian Pacific Journal of Cancer Prevention, 17(4):1933.

2. Andrée, S., Jira, W., Schwind, K. H., Wagner, H. and Schwägele, F. 2010. Chemical safety of meat and meat products. J. Meat Science, 86: 38-48.

3. AOAC "Association of Official Analytical Chemists" 2006 Official Methods of Analysis. 13 ${ }^{\text {th }}$ Ed., W. Horwitz (Editor), Academic Press, Washington, D. C., USA.

4. AOAC "Association of Official Analytical Chemists" 2016 Official methods of analysis. $17^{\text {th }}$ Ed., W. Horwitz. w, (Editor), Academic Press, Washington, D.C., USA

5. Archer, D.L. 2000. Evidence that ingested nitrate and nitrite are beneficial to health. Journal of Food Prot., 65(5):872-875.

6. ATSDR "Agency of Toxic Substance and Disease Registry" 2008. Toxicological profile for cadmium .U.S. Department of Health and Human Services, Atlanta, GA, USA.

7. Cemek, M., Akkaya, L., Birdane, Y.O., Seyrek, K., Bulut, S and Konuk, M. 2007. Nitrate and nitrite levels in fruity and natural minerals waters marketed in western Turkey. Journal of Food Composition and Analysis, 20(3-4)236-240.

8. Codex Alimentarius Commission Procedural Manual 2001. Maximum residual limits (MRLs).CAC/MRL, Rev., 12th Ed., 9(4): 149-158.

9. Cunningham, W. P. and Saigo, B. W. 1997. Environmental Science a Global Concern. $4^{\text {th }}$ Edn. WM Brown publisher, New York. 278-279.

10. EFSA "European Food Safety Authority "2009. Scientific opinion of the panel on contaminants in the food chain on a request from the European Commission on cadmium in food. EFSA J., 980: 1-139.

11. EL-Zahaby, D.I. 2013. Chemical evaluation of some food additives in meat products. Ph.D. Thesis., (Meat Hygiene). Fac. Vet. Med., Benha Univ.

12. Environmental Working Group 2010. Lead Compounds Retrieved November 5, 2010, from http://www.ewg.org/chemindex/term/455

13. ES "Egyptian Standards" 2005. Egyptian standards for requirements of minced meat, No: 1694. Egyptian standards for requirements of beef burger, No: 1688. Egyptian standards for requirements of sausage, No: 1972. Egyptian standards for requirements of luncheon meat, No: 1114.

14. ES "Egyptian Standards"2010. Maximum Levels for certain contaminants in foodstuffs. No 7136/2010. Egyptian Standards, Ministry of Industry, Egypt.

15. Ez-Eldain-Afaf, M. and El-Nemr, S.A. 2016. Assessment of nitrate and nitrite Residual Levels in some meat products. Egypt. J. Chem. Health., 2(2): 611-616.

16. Farag, H.El-S. and Abd-El- Fatah-Noha, R.M. 2011 Assessment of nitrite and ascrbic acid salts level in some meat products antir public health significance .Assuit Vet, Med.J., 57(129):1-22.

17. Gabriel-Hoha, V., Costăchescu-Elena, Leahu-Ana and Păsărin, B. 2014. Heavy metals contamination levels in 
processed meat marketed in Romania. Environmental Engineering and Management Journal, 13 (9): 2411-2415.

18. Govari and Pexara 2015. Nitrates and Nitrites in meat products. J. Hellenic Vet. Med. Soc., 66(3): 127-140.

19. Honikel, K.O. 2008. The use and the control of nitrate and nitrite for the processing of meat products. Meat Science, 78(1-2): 68-76.

20. Ibrahim-Eman, F. M. 2008. Bacteriological evaluation of some Street vended meat products. M. V. Sc. Thesis, Meat hygiene. Fac. Vet. Med., Menoufia Univ. (Sadat Branch).

21. Islam, G.M.R. and Hoque, M.M. 2013. Food safety regulation in Bangladesh, chemical hazard and some perception to overcome the dilemma. International Food Research Journal, 20(1): 47-58.

22. Karovicova, J. and Kohajdova, Z. 2005. Biogenic amines in food. Chemical Papers- Chemical Zvesti., 59(1): 70-79.

23. Lukáčová -Anetta, Golian, J., Massányi, P. and Formicki,G. 2014. Lead Concentration In: Meat and Meat Products of Different Origin. Scientific Journal for Food Industry, 8(1): 43-47.

24. Manea, L., Radulescu, C., Dulama, I.D., Teodorescu,S., Stirbescu, R.M., Chelarescu, E.D., Bucurica , I.A. 2017. Assessment of metals level in several meat products obtained through conventional and traditional methods. Article in Romanian Reports on Physics, December 2017. https://www.researchgate.net/publication/317826414.

25. Maricica, S., Silvia, S. and Petru, A. 2014. Overview of biological hazards associated with the consumption of the meat products. Journal of Agroalimentary Processes and Technologies, 20(2):192-197.

26. Meslam-Ebtsam, M.A.M. 2018. Chemical Studies On Some Locally Manufactured Meat Products. Ph.D. Thesis, (Meat Hygiene), Fac. Vet. Med., Benha Univ., Egypt.

27. Nayel, M.S. 2013. Studies on chemical preservatives in meat products. Ph.D. Thesis., (meat Hygiene). Fac. Vet. Med., Benha Univ.

28. NZFSA "New Zealand Food Safety Authority" 2012. Processed meats code of practice, part 4: HACCP Application.

29. Rezaei, M., Shariatifar N, Jahed Khaniki G, Javadzadeh M 2013.Nitrite in hamburgers in Arak, Iran. J. Food Addit .Contam. 6(4): 285-288.
30. Rubio, C., Gonzalez-Iglesias, T., Revert, C., Reguera, J.I., Gutierre, A.J. and Hardisson, A. 2005. Lead dietary intake in a Spanish Population (Canary Islands). J. of Agri. and Food Chemist, 53: 6543-6549.

31. Santamaria, P. 2006. Nitrate in vegetables: Toxicity, content, intake and EC regulation. Journal of the Science of Food and Agriculture, 86(1): 10-17.

32. Santhi, D. V., Balakrishnan, A., Kalaikannan, and Radhakrishnan, K. T. 2008. Presence of heavy metals in pork products in Chennai (India). Am. J. Food Technol., 3(3):192199

33. Shahat, M., Ammar, M.S., Ramzy, S. M. and Baz, A.M. 2017. Health Risk Assessment of Toxic Heavy Metals and Pesticides Residues of some Raw Animal Foods Collected from Egyptian Market. J. Curr. Sci. Int., 6(2): 421-430.

34. Shaltout, F. A., Hashim, F.M. and El-Nahas, s. 2015. Detection of some heavy metals in fish (Tilapia nilotica and Claris Lazera) at Menofia governorate. BVMJ, 29(1): 124 128.

35. Shibamoto, T. and Bjeldanes, L. F. 2000. Heavy contents in some meat products. Toxilo.Envir. Chem., 42: 113-117.

36. Skibsted, L.H. 2011. Nitric oxide and quality and safety of muscle based foods. Official Journal of the Nitric Oxide Society, 24(4):176-183.

37. Tsoumbaris, P. and Papadopoulou, T.H. 1994. Heavy metals in common foodstuff: Quantitative analysis. Bull. Eniron. Cntam. Toxicol. 53 (1): 61-66.

38. USDA "U.S. Department of Agriculture" 1997. Meat and poultry products hazards and control guide. Food Safety and Inspection Services. HACCP-2., Dc. Pp. 1-58 http://www.usda.gov.

39. Zahran- Dalia, A.and Hendy- Bassma, A. 2015. Heavy Metals and Trace Elements Composition in Certain Meat and Meat Products Sold in Egyptian Markets. Internationa Journal of Sciences: Basic and Applied Research (IJSBAR), 20, (1): 282-293.

40. Zhuang, P.M. B., McBride, H., Xia, N. and Li, Z.L. 2010 Health risk from heavy metals via consumption of food crops in the vicinity of Dabaoshanmine, South China., Sci. Total Environ., 407: 1551-1561. 